\title{
Correlation of islet cell antibodies and HLA-DR phenotypes with diabetes mellitus in adults
}

\author{
H. Gleichmann¹, B.Zörcher', B.Greulich', F. A.Gries ${ }^{1}$, H. R. Henrichs ${ }^{2}$, J. Bertrams ${ }^{3}$ and H. Kolb ${ }^{1}$ \\ 'Diabetes Research Institute, University of Düsseldorf, Düsseldorf, ${ }^{2}$ Diabetes Centre Quakenbrück, Quakenbrück and ${ }^{3}$ Elisabeth-Hospital, \\ Essen, FRG
}

\begin{abstract}
Summary. In a cross-sectional study, sera of 81 adult diabetic in-patients were tested for the presence of pancreatic islet cell antibodies (ICA), both IgG and complement-fixing. All patients had been well controlled initially with oral hypoglycaemic agents and therefore had been classified as having Type 2 (non-insulin-dependent) diabetes. However, 14 were subsequently classified as Type 1 (insulin-dependent) because they became insulin-dependent within 2 months of diagnosis. Ten of these patients (71\%) were ICA-positive. Sixty-seven patients had been non-insulin-dependent for at least 1 year after diagnosis. Circulating ICA were present in 18 patients and 16 of these (89\%) required insulin therapy. Secondary oral hypoglycaemic agent failure developed within a mean period of 3.7 years after diagnosis. In contrast, in the ICA-negative subgroup ( $n=49$ ) insulin treatment became necessary in 29 patients. Secondary oral hypoglycaemic agent failure of these patients had developed after a mean period of 8.4 years, which was significantly longer than in the ICA-positive patients $(p<0.01)$. Complement-fixing-ICA were detected only
\end{abstract}

in sera with an ICA-IgG titre of at least 8 , and its prevalence was similar in the sub-groups tested, i.e., the Type 1 diabetic patients and the patients with secondary oral hypoglycaemic agent failure. With HLA-DR typing, a significant excess of the DR3 antigen and heterozygous DR3/DR4 phenotypes was found in ICA-positive patients with secondary oral hypoglycaemic agent failure and in the Type 1 diabetic patients, which was comparable with the frequencies reported in juvenileonset Type 1 diabetes. The heterozygous DR3/W6 phenotype was significantly increased in the ICA-positive patients when compared with 13 ICA-negative patients. Thus, the presence of ICA and an excess of certain HLA-DR phenotypes identify a sub-group within the adult diabetic population with secondary oral hypoglycaemic agent failure which can be regarded as a retarded form of Type 1 diabetes.

Key words: Islet cell antibody, complement-fixing islet cell antibody, HLA-DR phenotypes.
Cytoplasmic antibodies to pancreatic islet cells (ICA) have been described in adult diabetic patients treated with oral hypoglycaemic agents and are associated with a high probability of becoming insulin-dependent within the near future. Considering the heterogeneity of diabetes, ICA-positive, apparently non-insulin-dependent diabetes may represent a retarded pathogenesis of Type 1 (insulin-dependent) diabetes [1, 2]. This is supported by the observation that ICA-positive patients, even though initially controlled with oral hypoglycaemic agents, expressed a significant prevalence of HLADR3 and heterozygous DR3/DR4 phenotypes comparable with the frequencies found in juvenile onset Type 1 diabetes [3-5].

\section{Subjects and methods}

\section{Subjects}

Eighty-one patients (aged 30-75 years, mean \pm SEM age $50 \pm 1$ years) were initially well controlled with diet or additional oral hypoglycae- mic agents and, therefore, had been classified as having Type 2 (noninsulin-dependent) diabetes. They were referred either to the diabeticclinics of Düsseldorf or Quakenbrück because of recent poor metabolic control. Serum samples obtained on admission were tested for ICA-IgG and complement-fixing ICA (CF-ICA). Classification was made on a clinical basis without knowledge of the ICA results. Type 1 diabetes was assumed, if satisfactory metabolic control could be achieved by insulin therapy, otherwise patients were classified as having Type 2 diabetes. Metabolic control was judged by recent weight change, ketonuria, haemoglobin $\mathrm{A}_{1}$ concentration, and fasting and post-prandial blood glucose values. In addition, basal immunoreactive insulin and maximal immunoreactive insulin response after $\beta$-cell stimulation with intravenous tolbutamide $(1 \mathrm{~g})$ alone or in combination with an oral glucose challenge $(100 \mathrm{~g})$ were determined. Secondary oral hypoglycaemic agent failure was diagnosed when satisfactory metabolic control could no longer be maintained with a strict diet and oral hypoglycaemic agents. These patients had persistent post-challenge blood glucose $>11.1 \mathrm{mmol} / \mathrm{l}$, haemoglobin $\mathrm{A}_{1}$ concentration $>8.5 \%$, and were suffering from glycosuria and occasional ketonuria. Their endogenous immunoreactive insulin secretion upon $\beta$-cell stimulation was also markedly decreased. Twenty-nine patients were recruited for retrospective HLA-typing and the calculated HLADR-antigen frequencies were compared with the values of 100 randomly selected unrelated healthy control subjects. 
Table 1. Classification and clinical and laboratory data from 81 adult apparently Type 2 diabetic patients according to their ICA status

\begin{tabular}{|c|c|c|c|c|c|c|c|}
\hline & \multicolumn{2}{|c|}{$\begin{array}{l}\text { Type } 1 \text { diabetic patients } \\
(n=14)\end{array}$} & \multicolumn{2}{|c|}{$\begin{array}{l}\text { Patients with } \\
\text { insulin-dependency } \\
\text { secondary to oral hypo- } \\
\text { glycaemic agent failure } \\
(n=45)\end{array}$} & \multicolumn{2}{|c|}{$\begin{array}{l}\text { Type } 2 \text { diabetic } \\
\text { patients } \\
(n=22)\end{array}$} & \multirow[t]{2}{*}{$\begin{array}{l}\text { Control } \\
\text { subjects } \\
(n=20)\end{array}$} \\
\hline & $\begin{array}{l}\text { ICA-positive } \\
(n=10)\end{array}$ & $\begin{array}{l}\text { ICA-negative } \\
(n=4)\end{array}$ & $\begin{array}{l}\text { ICA-positive } \\
(n=16)\end{array}$ & $\begin{array}{l}\text { ICA-negative } \\
(n=29)\end{array}$ & $\begin{array}{l}\text { ICA-positive } \\
(n=2)\end{array}$ & $\begin{array}{l}\text { ICA-negative } \\
(n=20)\end{array}$ & \\
\hline $\begin{array}{l}\text { Time since diagnosis } \\
\text { (years) }\end{array}$ & $<0.2$ & $<0.2$ & $\begin{array}{l}3.7 \\
(1-15)^{\mathrm{c}}\end{array}$ & $\begin{array}{l}8.4 \\
(1-17)^{c}\end{array}$ & $\begin{array}{l}1.3 \\
(0.5-2)\end{array}$ & $\begin{array}{l}4.8 \\
(0.5-15)\end{array}$ & \\
\hline Age at diagnosis (years) & $\begin{array}{c}44.3 \\
(30-62)\end{array}$ & $\begin{array}{l}47.3 \\
(38-71)\end{array}$ & $\begin{array}{l}46.1 \\
(30-75)\end{array}$ & $\begin{array}{l}52.3 \\
(31-75)\end{array}$ & $\begin{array}{c}39.0 \\
(34-44)\end{array}$ & $\begin{array}{l}52.0 \\
(30-74)\end{array}$ & \\
\hline
\end{tabular}

Immunoreactive insulin results expressed as mean \pm SEM; age expressed as mean with range in parentheses.

${ }^{a}$ maximal additional secretion upon $\beta$-cell stimulation with intravenous tolbutamide or in combination with oral glucose challenge.

b obtained after 5 min; ${ }^{c} p<0.01$

\section{Methods}

ICA-IgG and CF-ICA were detected by indirect immunofluorescence, using cryostat sections of human pancreas [6-8]. HLA-DR1, 2, $3,4,5, \mathrm{~W} 6,7$, W8 and W10 specificities were recognized on peripheral B-lymphocytes [9]. Statistical significances were calculated using the $\chi^{2}$ test and the Wilcoxon-Mann-Whitney U-test.

\section{Results}

\section{Clinical classification}

Fourteen of the 81 patients required insulin therapy within 2 months of diagnosis, and this group was termed adult-onset Type 1 diabetes. Sixty-seven patients, who had been well controlled with diet or additional oral hypoglycaemic agents for at least 1 year, were categorised as Type 2 diabetic patients. Of these, 45 developed secondary oral hypoglycaemic agent failure and 22 remained satisfactorily controlled with diet or additional oral hypoglycaemic agents. The patients requiring insulin therapy suffered from $\beta$-cell deficiency, as demonstrated by low basal immunoreactive insulin values and failure of insulin secretion upon stimulation with intravenous tolbutamide. In contrast, the Type 2 diabetic sub-groups had low basal immunoreactive insulin values but responded with markedly increased levels upon stimulation with tolbutamide alone or combined with oral glucose challenge (Table 1).

\section{High association of ICA and Type I diabetes}

ICA-IgG were observed in one $(0.7 \%)$ and CF-ICA in none of 150 control sera obtained from healthy subjects. ICA were found in $10(71 \%)$ of the 14 adult Type 1 diabetic patients. In 18 out of the 67 apparent Type 2 diabetic patients, ICA were detected, and 16 of this sub- group ( $89 \%$ ) had developed secondary oral hypoglycaemic agent failure, while only two remained non-insulindependent. Of the 49 ICA-negative patients, 29 required insulin therapy. The time interval between diagnosis of diabetes and development of insulin dependency was significantly shorter in the ICA-positive than in the ICA-negative sub-groups $(p=0.01 ;$ mean \pm SEM $3.7 \pm 0.9$ and $8.4 \pm 1.1$ years, respectively; Table 1 ). ICA were detected in $50 \%$ of the ICA-positive sera and were strongly associated with an ICA-titre of at least of $8 ; 12$ out of 16 of such high-titre sera contained CF-ICA. There was no difference in prevalence of CF-ICA in the sera of either adult Type 1, secondary oral hypoglycaemic agent failure, or Type 2 diabetic sub-groups.

\section{HLD-DR phenotype frequencies in ICA-positive Type I diabetic patients}

Sixteen of the 29 patients typed for HLA-DR antigens were ICA-positive, comprising 11 diabetic patients classified as secondary oral hypoglycaemic agent failures and five with adult Type 1 diabetes. The remaining 13 were ICA-negative and comprised eight with secondary oral hypoglycaemic agent failure and five with Type 2 diabetes. The HLA-DR frequencies of the two ICApositive and two ICA-negative sub-groups, respectively, were combined because there were no differences in DR frequencies among the corresponding sub-groups. In the ICA-positive population, DR3, and heterozygous DR3/DR4 and DR3/W6 phenotype frequencies, were significantly increased (Fig. $1 ; 75 \%, 31.3 \%$ and $25 \%$ versus $30 \%, 6 \%$ and $3 \%$ in the control group, respectively), whereas DR2 and DR5 phenotype frequencies were significantly decreased (6.3 and $0 \%$ versus 31 and $27 \%$ in the controls, respectively). In contrast, the ICA-negative sub-group had antigen frequencies similar to the control population. 


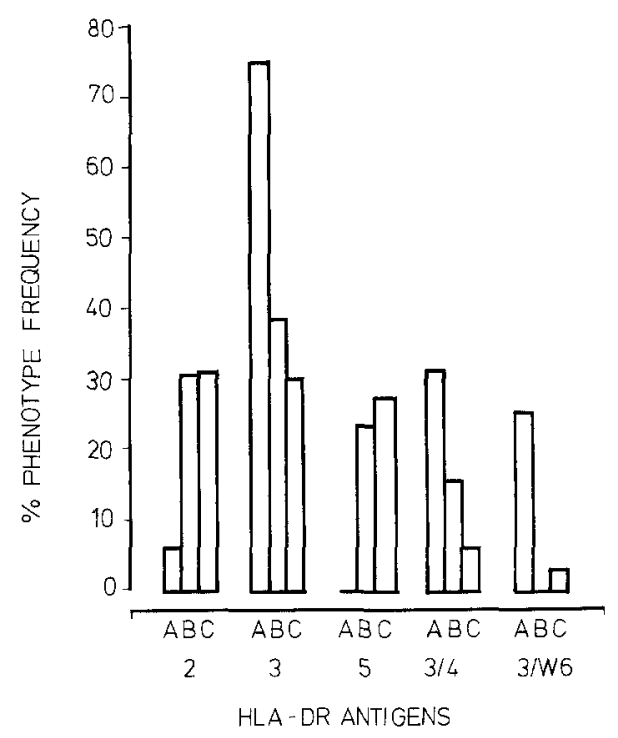

Fig. 1. HLA-DR phenotype frequencies in 16 ICA-positive (A), 13 ICA-negative (B) diabetic patients and 100 control subjects (C). When comparing the frequencies of the ICA-positive and ICA-negative sub-groups, significant differences were found with respect to the DR3, DR5 and DR3/W6 frequencies $(p<0.05)$. When comparing the values of the ICA-positive sub-group with those of the control population, significant deviations were found at DR3 $(p<0.0005)$, DR5 $(p<0.02)$, DR3/DR4 $(p<0.001)$ and DR3/W6 $(p<0.0006)$. The differences between the ICA-negative sub-group and the control values were not significant

\section{Discussion}

The present results of a cross-sectional investigation confirm and extend the data of other studies [1,2] on the value of ICA as an in vitro test predicting the likelihood of forthcoming secondary oral hypoglycaemic agent failure in apparent Type 2 diabetic subjects. Of 18 ICApositive patients, $16(89 \%)$ developed secondary oral hypoglycaemic agent failure after a mean period of 3.7 years. This incidence is similar to the data resulting from a prospective study of Irvine et al. [1]. By acturial statistics, these authors calculated that the probability of becoming insulin-dependent within 5 years is $86 \%$ for ICA-positive patients controlled initially with oral hypoglycaemic agents. The prevalence of $71 \%$ for ICApositive patients in the adult Type 1 diabetic group is similar to the ICA prevalence in juvenile Type 1 patients as originally described by Lendrum et al. [10]. Our observation that there is a positive correlation between CF-ICA and the titre of ICA confirms recently published results in juvenile Type 1 diabetic subjects [11]. However, we did not find that the presence of CF-ICA is more strongly associated with subsequent insulin dependency (results not shown). These data support recent observations by Mustonen et al. [12], but contrast with other reports $[2,7]$.
In our study, ICA-positive patients with adult Type 1 diabetes or with secondary oral hypoglycaemic agent failure expressed HLA-DR phenotype frequencies similar to those with juvenile-onset Type 1 diabetes [3-5], whereas the ICA-negative sub-groups failed to do so. Thus, the notion that ICA-positive diabetes controlled with oral hypoglycaemic agents represents a clinically and pathogenically retarded form of Type 1 diabetes [1] is supported. The significance of the observed positive association of DR3/W6 heterozygous phenotypes and presence of ICA will be evaluated further in a prospective study in apparent Type 2 diabetes.

\section{References}

1. Irvine WJ, Sawers JSA, Feek CM, Prescott RJ, Duncan LJP (1979) The value of islet cell antibody in predicting secondary failure of oral hypoglycemic agent therapy in diabetes mellitus. J Clin Lab Immunol 2: 23-26

2. Di Mario U, Irvine WJ, Borsey DQ, Kyner JL, Weston J, Galfo C (1983) Immune abnormalities in diabetic patients not requiring insulin at diagnosis. Diabetologia 25: 392-395

3. Svejgaard A, Platz P, Ryder LP (1980) Insulin-dependent diabetes mellitus. Joint Report. In: Terasaki PI (ed) Histocompatibility Testing 1980. UCLA Tissue Typing Laboratory, Los Angeles, California, pp 638-656

4. Deschamps I, Lestradet H, Bonaitï C, Schmid M, Busson M, Benajam A, Marcelli-Barge A, Hors J (1980) HLA genotype studies in juvenile insulin-dependent diabetes. Diabetologia 19: 189-193

5. Wolf E, Spencer KM, Cudworth AG (1983) The genetic susceptibility to Type 1 (insulin-dependent) diabetes: analysis of the HLADR association. Diabetologia 24: 224-230

6. Bottazzo GF, Florin-Christensen A, Doniach D (1974) Islet-cell antibodies in diabetes with autoimmune polyendocrine deficiencies. Lancet 2: 1279-1283

7. Bottazzo GF, Dean BM, Gorsuch AN, Cudworth AG, Doniach D (1980) Complement-fixing islet-cell antibodies in Type-I diabetes: possible monitors of active beta-cell damage. Lancet $1: 668-672$

8. Kolb H, Krügener G, Gries FA, Bellmann O (1983) Islet cell autoantibodies: which method? Lancet 1: 479 (Letter)

9. Danilovs J, Terasaki PI, Parks MS, Ayoub G (1980) B lymphocyte isolation by thrombin-nylon wool Joint Report. In: Terasaki PI (ed) Histocompatibility Testing 1980. UCLA Tissue Typing Laboratory, Los Angeles, California, pp 287-288

10. Lendrum R, Walker GJ, Cudworth AG, Theophanides C, Pyke DA, Bloom A, Gamble DR (1976) Islet-cell antibodies in diabetes mellitus. Lancet 2: 1273-1276

11. Bruining GJ, Molenaar J, Tuk CW, Lindeman J, Bruining HA, Marner B (1984) Clinical time-course and characteristics of islet cell cytoplasmic antibodies in childhood diabetes. Diabetologia 26: $24-29$

12. Mustonen A, Knip M, Åkerblom HK (1983) An association between complement-fixing cytoplasmic islet-cell antibodies and endogenous insulin secretion in children with insulin-dependent diabetes mellitus. Diabetes 32: 743-747

Dr. H.Gleichmann

Diabetes Forschungsinstitut

Universität Düsseldorf

Auf'm Hennekamp 65

D-4000 Düsseldorf 1

FRG 